\title{
Psychology
}

Gladuell, 2010 - Gladuell M. Genii i autsaidery: Pochemu odnim vse, a drugim nychego? / per. s angl. 2-e izd. Moskva : OOO Yunaited Press. 2010. 256 s.

Gottman, Dekler, 2018 - Gottman Dzh., Dekler Dzh. Emotsionalnyy intellekt rebenka. Prakticheskoe rukovodstvo dlia roditeley. Moskva : OOO Mann, Ivanov i Ferber, 2018. $288 \mathrm{~s}$.

Davydov, 2000 - Davydov V. V. Vidy obobshcheniia v obuchenii: Logiko-psykhologicheskie problemy postroeniia uchebnykh predmetov. Moskva : Pedagogicheskoe obshchestvo Rossii, 2000. $480 \mathrm{~s}$.

Zarytska, 2011 - Zarytska V. V. Rozvytok emotsiinoho intelektu v konteksti kompetentnisno spriamovanoi osvity. Kompetentnisno spriamovana osvita: pershyi dosvid, porivnialni pidkhody, perspektyvy: zb. Materialiv dop. uchasn. Vseukr. nauk.-prakt. konf. Kyyiv, 2011. S. 92.

Muzychuk, 2012 - Muzychuk O. O. Kazka iak zasib rozvytku osobystisnykh tsinnostei molodshykh shkoliariv. Problemy suchasnoyi psykholohiyi: zb. nauk. prats. Kamianets-Podilskyi. Aksioma, 2012. Vyp. 17. S. 317-327.

Ponomarev, 1999 - Ponomarev Ya. A. Psykhologiia tvoreniia: izbrannye psykhologicheskye trudy. Voronezh : NPO Modek. 1999. $480 \mathrm{~s}$.

Savchenko, 2015 - Savchenko Yu. Yu. Rozvytok emotsiinoho intelektu uchniv molodshoho shkilnoho viku. Osvita ta rozvytok obdarovanoyi osobystosti. 2014. Vyp. № 12 (31) S. 12-16. URL: http://nbuv.gov.ua/UJRN/Otros_2014_12_5 (data zvernennia: 8.07.2019).

\author{
Галина Радчук, \\ доктор психологічних наук, \\ професор, завідувач кафедри \\ практичної психології \\ Тернопільського національного \\ університету \\ імені Володимира Гнатюка
}

\author{
Halyna Radchuk, \\ Doctor of Psychological Sciences, \\ Professor, \\ Head of the Department \\ of Practical Psychology \\ of Volodymyr Hnatiuk Ternopil \\ National University
}

\section{КУЛЬТУРНО-ПСИХОЛОГІЧНИЙ ПІДХІД У КОНТЕКСТІ СІМЕЙНОГО ВИХОВАННЯ}

\begin{abstract}
У статті проаналізовано концептуальні засади культурно-психологічного підходу в сімейному вихованні. Виокремлено три основних підходи до визначення культури: иіннісний (аксіологічний), діяльнісний та особистісний. Визначено, щяо культурний розвиток досить часто розглядається з точки зору розвитку діяльності, щзо приводить до редукування иілісного становлення особистості дитини, до розвитку виключно інтелектуальних структур. Зауважено, що в поясненні місия людини в культурі як $і$ раніше використовується об'єктний підхід, у відповідності з яким культура надбудовується над людиною, а не проявляється у ї̈ власному бутті та життєтворчості. Доведено, щзо культура - ие середовище, яке вирощує $i$ живить розвиток особистості, а культурно-психологічний підхід у сфері сімейного виховання передбачає розвиток дитини як особистості, індивідуальності й активного суб 'єкта діяльності та може бути реалізований лише на основі побудови діалогічної стратегї діяльності дорослого. Обірунтовано освітній діалог, як культурно доиільну форму навчання, спрямовану на перетворення внутрішнього, духовного досвіду батьків і майбутніх батьків та набуття нового в ияарині сімейного виховання, а також розвитку діалогу як необхідної умови розгортання особистісного потенціалу дитини у сім'ї. Розроблено освітню програму, в якій діалог виконує двоєдине завдання: 1) як умова становлення повноцінної особистості дитини в сім' $\dddot{i}$; 2) як ефективна форма навчання батьків інноваційним підходам у сфері сімейного виховання. Визначено методичні особливості
\end{abstract}


та структуру освітньої програми у формі освітнього діалогу. Наведено результати апробаиії иієї програми у просвітницькій роботі з батьками і майбутніми батьками, щэо переконливо засвідчують ї̈ ефективність.

Ключові слова: культура, діалог, освітній діалог, сімейне виховання, особистість.

The article analyzes the conceptual foundations of the cultural-psychological approach in family education. There are three main approaches to defining culture: value-(axiological), activityand personality-based. It is noted that cultural development is often considered from the point of view of activity development, which leads to the development of exclusively intellectual structures and thus reduces holistic formation of the child's personality. An object-based approach is still used when explaining a person's place in culture, whereby culture is superimposed on a person, but not manifested in his or her own life and creativity. The authors argues that culture is an environment that nurtures and nourishes development of the individual. The cultural and psychological approach in the field of family education envisages development of a child as its own personality, as an individual and active subject of activity. This approach can be implemented only when adults implement dialogical strategy in their activity. Educational dialogue is defined as an adequate and culturally appropriate form of education aimed at transforming the internal, spiritual experience of parents and future parents and acquiring a new one in the field of family education. Dialogue development is a necessary condition for the growth of child's personal potential in a family. In the educational program presented this article, the dialogue performs a twofold task: 1) as a condition for development of child's self-sufficient personality in a family; 2) as an effective form of teaching parents innovative approaches in the field of family education. The author identifies methodological features and structure of educational program in the form of educational dialogue. The article also presents the results of program testing in educational work with parents and future parents, which prove its effectiveness.

Keywords: culture, dialogue, educational dialogue, family education, personality.

Постановка проблеми. Увага сучасних дослідників до культурнопсихологічного підходу пов'язана 3 його спрямованістю на цілісний особистісний розвиток. Взаємодія людини і культури існує та проявляється як діалектична єдність джерела та результату їхнього існування, в якому i першим, і другим є ці два феномени, що взаємно породжують один одного. Особливо важливим є культурно-психологічний підхід у сфері сімейного виховання, що спрямований на становлення дитини як цілісної особистості, індивідуальності й активного суб'єкта діяльності.

Аналіз досліджень і публікацій. Розуміння культури склалося в рамках екзистенціально-гуманітарної філософії (В. Дільтей, Г. Ріккерт, Е. Кассірер, М. Вебер, О. Шпенглер, Е. Гуссерль, М. Хайдеггер, Г. Гадамер та ін.) і духовно-діалогічної культурології (М. Бахтін, М. Бердяєв, А. Лосєв, М. Бубер, Е. Левінас, В. Біблер, М. Мамардашвілі та ін.).

У даний час у психологічній науці можна виокремити три основних підходи до визначення культури: ціннісний (аксіологічний), діяльнісний та особистісний. Ціннісна концепція культури підкреслює роль і значення ідеальної моделі. Тут діє механізм інтеріоризації культурних цінностей у внутрішній світ особистості. М. Мамардашвілі критикував розуміння культури як сукупності цінностей, які знаходяться поза людиною: «Культура не є сукупністю високих понять чи високих цінностей. Вона не $\epsilon$ цим хоча би тому, що ніякі цінності, ніякі досягнення і ніякі механізми не є ... гарантією. 3 будь-яких вершин культури завжди можна зірватися у 


\section{Psychology}

безодню» [Мамардашвили, 1992: c. 144]. Діяльнісна концепція розглядає культуру як специфічний (культурний) спосіб діяльності. Тут діє механізм екстеріоризації - перетворення людських сил і здібностей в об'єктивні соціально-значущі продукти діяльності і цінності. Саме у вітчизняній традиції культурний розвиток досить часто розглядається 3 точки зору розвитку діяльності. Проте гіпертрофована апеляція до діяльності приводить до редукування цілісного становлення особистості дитини та розвитку виключно інтелектуальних структур.

Як справедливо зауважує О. Старовойтенко, особистість виступає в таких підходах «моделлю усередненого носія культури», при цьому «особлива увага приділяється об'єктивній детермінації культурного становлення свідомості, проективних систем і поведінки людини на шкоду суб'єктній, ціннісно-смисловій самодетермінації» [Старовойтенко, 2006: c. 233]. В особистісній концепції під культурою розуміють усі прояви людської суб'єктивності, властивості і якості, що характеризують ступінь культурності суспільства: рівень свободи, освіченості, моралі, духовності людей, здатності до культурного розвитку тощо. Культура виступає тут як середовище, яке вирощує i живить розвиток особистості. Механізмом розвитку особистості в культурі виступає персоналізація.

Власне особистісний підхід було покладено в основу нашого дослідження. Водночас варто зауважити, що у поясненні місця людини в культурі як і раніше використовується об'єктний підхід, у відповідності 3 яким культура надбудовується над людиною, а не проявляється у іï власному бутті, життєтворчості, духовності, свободі.

Особливо великий інтерес до культурного підходу у царині сімейного виховання, де багато уваги приділяється кроскультурним порівнянням, а також вивченню психолого-педагогічної роботи з сім'ями у конкретній культурі, наративним методам сімейної психотерапії. Проте часто не враховується вся психологічна глибина впливу культури на розвиток особистості в сімейному оточенні.

М. Коул говорить про «необхідність грунтувати теоретичні побудови та емпіричні висновки на реальному предметі психологічного аналізу, що відповідає подіям повсякденного життя, котрі реально переживаються» [Коул, 1997: c. 249]. На його думку, хоча у радянській психології завдання вивчення психіки у контексті діяльності офіційно проголошувалось одним 3 основних принципів психологічного дослідження - «принцип єдності свідомості та діяльності», проте ніколи акцент не ставився на аналізі повсякденної діяльності, мова зазвичай йшла про формально (інституційно) організовані види діяльності: ігрову, навчальну та трудову [Коул, 1997].

Культурно-історична теорія розвитку психіки i розвитку особистості розроблялася Л. Виготським і його школою в 20-30 роках ХХ ст. У цьому підході Л. Виготський пропонує розглядати соціальне середовище не як один із чинників, а як основне джерело розвитку 
особистості [Выготский, 2003]. Все, що робить дитина, вона робить у співпраці, разом 3 дорослими. Саме співпраця 3 іншими людьми $\epsilon$ головним джерелом розвитку особистості дитини, а найважливішою рисою свідомості $€$ діалогічність. Л. Виготський вводить поняття «зона найближчого розвитку» - це той простір дій, які дитина не може виконати самостійно, але може здійснити разом з дорослими і завдяки їм. Для нього особистість $є$ поняття соціальне, те, що в ньому привнесено культурою. Особистість не вроджена, але виникає в результаті культурного розвитку. Інший аспект теорії Л. Виготського - уявлення про розвиток як про стадіальний процес, де періоди плавного накопичення нових можливостей змінюються етапами кризи. Криза, для Л. Виготського, - це бурхливий, іноді драматичний етап зламу (або переосмислення) старого і формування нового способу життя. Кризи бувають болючі, але вони, за поглядами автора, неминучі. 3 іншого боку, явне неблагополуччя дитини під час кризи зовсім не закономірність, а лише наслідок безграмотної поведінки батьків та інших дорослих, які виховують дитину. I ще один важливий аспект даної концепції -це теза про активність дитини [Выготский, 2003]. Тому, важливо підкреслити, що концепція Л. Виготського містить потужний евристичний потенціал, особливо в контексті сімейного виховання.

Проте культурно-історична психологія Л. Виготського не враховує сімейного виміру людського життя, ту обставину, що розвиток людини, як правило, відбувається в умовах біологічної сім'ї. «Можливо саме тут необхідно побачити зону найближчого розвитку культурно-історичної психології, оскільки сім'я - одна 3 найістотніших та найфундаментальніших характеристик соціального оточення, що відображає біосоціальну природу людини» [Старовойтенко, 2006: с. 125].

Формулювання цілей статmі. Метою нашого дослідження виступило теоретичне обгрунтування концептуальних та методичних засад культурно-психологічного підходу в сімейному вихованні та емпірична перевірка ефективності цього підходу у педагогічній практиці.

Виклад основного матеріалу. На думку О. Асмолова, В. Давидова, О. Сапогової, саме сучасна культурно-історична психологія повинна стати методологічною основою при побудові концепцій, що пояснюють i об’єктивують феномен людини. Певний вклад у дослідження культурних основ становлення особистості внесли такі вчені, як М. Бахтін (ідея діалогу культур), М. Бердяєв, П. Флоренський (уявлення про людину як епіцентр культури, iï найвищу духовну цінність), Л. Виготський (культурноісторичний підхід до розвитку особистості), Г. Батищев, М. Мамардашвілі (уявлення про культурне поле особистості), О. Асмолов (протиставлення двох освітніх парадигм - культури корисності і культури гідності), Є. Бондаревська (культурологічна концепція особистісно зорієнтованої освіти). 3 цих досліджень випливає, що культурна сутність людини $€$ системотвірним компонентом пї цілісної життєдіяльності. Освіта - це 


\section{Psychology}

складний культурний процес, рушійними силами якого є особистісні смисли, діалог та співпраця його учасників у досягненні цілей культурного саморозвитку. Діалог представлений у культурному підході як універсальний простір розвитку особистості. Взятий як метод, діалог може розглядатися як культурно доцільна інтегративна гуманітарна технологія становлення особистості дитини, актуалізації ії саморозвитку.

Проте, можна констатувати той факт, що ставлення до особистості в освітній практиці, i, насамперед, у практиці сімейного виховання відповідає панівній у суспільстві парадигмі: особистість і до сьогодні розглядається як те, що потрібно «формувати». Якщо в освіті ще помітні деякі прогресивні зміни, то у сфері сімейного виховання панують традиційні стереотипи.

У цьому зв'язку вбачаємо нагальну необхідність впровадження діалогічних форм навчання майбутніх педагогів (i, водночас, майбутніх батьків), а також батьків 3 метою зміни ціннісно-смислових настанов у сфері сімейного виховання, розвитку діалогу як найбільш необхідної умови розгортання особистісного потенціалу дитини.

Виходячи з вищеозначених концептуальних засад, ми розробили й апробували у педагогічній практиці освітній діалог, спрямований перш за все на перетворення внутрішнього, духовного досвіду педагогів, батьків і майбутніх батьків та набуття нового у царині сімейного виховання. Освітній діалог розглядається нами як форма специфічно організованого навчання, метою якої є засвоєння педагогічних знань на ціннісно-смисловому рівні, а також форма спілкування, в якій вирішуються проблеми розвитку особистості, надання ій психологічної підтримки. Він націлений на становлення нових смислових структур, котрі емоційно проживаються учасниками освітнього процесу, осмислюються ними. При цьому якщо будь-яка комунікативна технологія існує в парадигмі суб'єкт-суб'єктного взаємообміну, діалогічний підхід дозволяє інтегрувати єдиний смисл.

У представленій, розробленій нами, освітній програмі діалог виконує двоєдине завдання: 1) як умова становлення повноцінної особистості дитини; 2) як ефективна форма навчання педагогів та батьків інноваційним підходам у сфері сімейного виховання.

Інакше кажучи, у процесі навчання за допомогою діалогічної взаємодії відбувається поглиблення саморозуміння та адекватне розуміння поведінки, переживань, думок дитини, ціннісне ставлення до особистості дитини, формується вміння асертивно встановлювати психологічні кордони, адекватно висловлювати свої переживання та почуття, тобто розвивається вміння вибудовувати повноцінний діалог у взаєминах 3 дитиною.

Теоретичний аналіз психолого-педагогічних джерел та власний досвід просвітницької роботи 3 педагогами, психологами та батьками показав, що освітнє діалогічне середовище повинне конструюватися 3 врахуванням таких параметрів: 
а) контекстуальність щодо внутрішнього світу особистості, коли текст, що вивчається, лежить в «контексті» особистісно-смислової сфери учасників освітньої програми; б) відкритість як спосіб представлення в освітньому матеріалі відкритих для доповнення, нестійких, неврівноважених, парадоксальних (феноменальних) фактів, які не мають однозначного тлумачення; в) метафоричність освітнього матеріалу як механізм активізації синкретичного емоційного схоплення цілісної ситуації (в єдності асоціативних, інтуїтивних, логічних зв'язків) і актуалізації смислового потенціалу особистості; г) ігрові форми навчальної взаємодії 3 притаманною для гри свободою, змагальністю, що актуалізує проблему самореалізації особистості і дозволяє їй у деякій мірі актуалізувати свій потенціал, створюючи власний світ, особливий простір, програючи в ньому свої ролі і моделі реальності; через імітацію життєвої ситуації, яка дозволяє апробувати цінність у дії й у спілкуванні з іншими людьми, порівняти з іншими цінностями; д) суб'єкт-суб'єктний характер стосунків учасників освітньої програми як взаємодія цілісної особистості зі світом культури, в якому відбувається прояснення, навіть перегляд своїх цінностей, пошук шляхів саморозвитку i, водночас, активно розвивається рефлексивна функція особистості.

Реалізуючи даний підхід, ми використовували різні інтерактивні методи та форми, які допомагають організувати і розгорнути суб'єктсуб'єктну взаємодію між учасниками освітньої програми, залучити до процесу навчання цілісну особистість, а саме: 1) рольові ігри; 2) групові дискусії; 3) наративні розповіді; 4) творчі завдання; 5) мозкову атаку; 6) інтерактивні міні-лекції; 7) колажі; 8) рефлексивні коментарі; 9) повчальні історії, яскраві метафори, казкові розповіді; 10) психогімнастичні, ігрові вправи, вправи на активізацію, рефлексію тощо.

Власне вищеозначені теоретичні та методичні аспекти освітнього діалогу лягли в основу побудови освітньої програми «Діалог як умова становлення повноцінної особистості дитини в сім'ї», яка складається 3 цілої низки окремих тематичних модулів. У нашому контексті модуль - це відносно самостійна одиниця («цеглинка»), 3 яких вибудовується оригінальна конструкція конкретної освітньої програми. Логіка програми полягає в наступному: кожен модуль, реалізуючи свою мету, допомагає учасникам як батькам чи майбутнім батькам поступово усвідомити свій суб' єктний потенціал, далі - усвідомлювати цю суб'єктність як серцевину повноцінної особистості у дітях і поступово, долаючи стереотипи, відпрацьовувати навички повноцінного діалогу з дітьми. Тематичні модулі взаємно доповнюють один одного і кожен 3 них вносить свій вклад у реалізацію основних завдань освітньої програми. Освітня програма «Діалог як умова становлення повноцінної особистості дитини в сім’ї» складається з послідовної низки таких модулів:

1. Концептуальні засади тренінгу (усвідомлення концептуальних засад освітньої програми та основних шляхів сімейного виховання). 


\section{Psychology}

2. Світ дитини: особливості становлення (розвиток цілісного бачення становлення особистості дитини; засвоєння знань про вікові особливості іiі психічного розвитку, актуалізація дитячих спогадів, особистісної інтерпретації становлення особистості дитини).

3. Спілкування 3 дитиною (розширення знань про механізми та особливості комунікативної взаємодії $з$ дітьми, розвиток комунікативних умінь і навичок).

4. Самооцінка дитини (усвідомлення центральних механізмів особистісного розвитку, розвиток уміння конструювання сприятливих умов для становлення стрижневих особистісних властивостей, розвиток навичок самоаналізу і рефлексіі).

5. Особистісний простір у сім'ї (розширення знань про психологічні кордони особистості, відпрацювання навичок асертивної поведінки у різних життєвих ситуаціях).

6. Усвідомлення наслідків негативної поведінки (усвідомлення i критичне осмислення стійких стереотипів у сімейному вихованні, відпрацювання навичок конструктивної взаємодії у ситуаціях негативної поведінки дітей).

7. Емоції та поведінка дитини (розширення i збагачення знань щодо ролі емоційної сфери у становленні особистості дитини, відпрацювання вмінь емпатійного реагування на дитячу поведінку).

8. Діалогічна взаємодія в сімейних конфліктах (конструювання оптимальних умов для вирішення конфліктних сімейних ситуацій, відпрацювання вмінь конструктивної (діалогічної) взаємодії в таких ситуаціях).

9. Підсумки (узагальнення результатів навчання, побудова реальних планів утілення ціннісних настанов та одержаних знань, умінь та навичок у життя) [Радчук, 2015].

Після проведення даної освітньої програми 3 майбутніми педагогами (та водночас майбутніми батьками) впродовж трьох повних днів для того, щоб відслідкувати, наскільки діалогічне середовище, змодельоване в освітній програмі, виступило спонукою для зовнішнього ініціювання внутрішніх ціннісно-смислових процесів особистості кожного учасника, ми використали методику ситуативної самоактуалізації особистості Т. Дубовицької [Дубовицкая, 2005]. IIÏ мета - діагностика ступеню самоактуалізації, що переживається людиною в різних контекстах (ситуаціях). Методика представляє собою анкету, яка включає 14 пар характеристик особистості, що відображають стан самоактуалізації людини у відповідності 3 описом самоактуалізованої особистості за А. Маслоу. Учасники освітнього діалогу повинні були оцінити себе (від 1 до 5 балів) за запропонованими параметрами, відповідаючи на запитання: 1) «Який я взагалі (частіше всього)?»; 2) «Який я на заняттях освітньої програми?». Відтак, за допомогою цієї методики ми намагалися виявити, якою мірою освітня програма сприяє самоактуалізаії особистості, 
актуалізує іï суб'єктний потенціал, створюючи діалогічне середовище. Розподіл тестових балів за кожним запитанням в учасників занять (об'єм вибірки - 27 чоловік) представлено у табл. 1.

Таблиця 1

Розподіл балів загальної та ситуативної самоактуалізації учасників освітньої програми у формі діалогу

\begin{tabular}{|c|c|c|c|c|c|}
\hline Питання & $\begin{array}{c}\text { Мінімаль- } \\
\text { ний } \\
\text { бал }\end{array}$ & $\begin{array}{c}\text { Максималь- } \\
\text { ний } \\
\text { бал }\end{array}$ & $\begin{array}{c}\text { Середнє } \\
\text { арифме- } \\
\text { тичне }\end{array}$ & Медіана & $\begin{array}{c}\text { Середнє } \\
\text { квадратичне } \\
\text { відхилення }\end{array}$ \\
\hline $\begin{array}{c}\text { Який Я } \\
\text { взагалі? }\end{array}$ & 37 & 64 & 50.3 & 52 & 7.1 \\
\hline $\begin{array}{c}\text { Який Я на } \\
\text { заняттях? }\end{array}$ & 43 & 70 & 56.5 & 56 & 4.2 \\
\hline
\end{tabular}

Представлені результати загалом свідчать про високі показники ситуативної самоактуалізації особистості в середовищі, змодельованому засобами освітнього діалогу. Як відзначають самі учасники, у процесі занять вони «переживають позитивні емоції, піднесення» (середній бал максимальний - 5.0), «захоплені тим, що відбувається» (5.0), «вирішують важливі проблеми, приймають важливі рішення, відкривають нове для себе» (4.8), «причетні до спільної справи, значущої для багатьох» (4.8).

Висновки. Отже, можна стверджувати, що культурнопсихологічний підхід у сфері сімейного виховання передбачає розвиток дитини як особистості, індивідуальності й активного суб'єкта діяльності та може бути реалізований лише на основі побудови діалогічної стратегії діяльності дорослого. Діалог $\epsilon$, справді, максимально адекватним середовищем розвитку особистості. Концепція діалогу дозволяє краще зрозуміти й альтернативні способи міжособистісної взаємодії (авторитарний, ліберальний, маніпулятивний та ін.), окреслити орієнтири i засоби їх «діалогізації».

Водночас, представлена у формі освітнього діалогу інноваційна освітня програма «Діалог як умова становлення повноцінної особистості дитини у сім “̈̈» актуалізує суб'єктний потенціал учасників як майбутніх батьків та педагогів, сприяє становленню ціннісно-смислових настанов у сфері сімейного виховання та розвитку діалогу як найбільш ефективного механізму розгортання особистісного потенціалу дитини.

\section{ЛIТЕРАТУРА}

Выготский, 2003 - Выготский Л. С. Психология развития человека. Москва : «Смысл», «Эксмо», 2003. $1136 \mathrm{c}$.

Дубовицкая, 2005 - Дубовицкая Т. Д. Методика диагностики ситуативной самоактуализации личности: контекстный подход. Психологический журнал, 2005. № 5. С. 70-78.

Коул, 1997 - Коул М. Культурно-историческая психология: Наука будущего / пер. с англ. Москва : Когито-Центр, 1997. 432 с.

Мамардашвили, 1992 - Мамардашвили М. К. Как я понимаю философию. Москва : Культура, 
Радчук, 2015 - Радчук Г. К. Психолого-педагогічні засади впровадження освітнього діалогу у навчальний процес викладачами ВНЗ. Проблеми гуманітарних наук: Збірник наукових прачь Дрогобищького держсвного педагогічного університету імені Івана Франка. Серія «Психологія». Дрогобич : Видавничий відділ ДДПУ імені Івана Франка, 2015. Випуск тридцять п'ятий. С. 85-101.

Старовойтенко, 2006 - Старовойтенко О. Б. Проблема суб'єкта в культурній психології особистості. Людина. Суб'єкт. Вчинок: Філософсько-психологічні студії / за заг. ред. В. О. Татенка. Київ, Либідь, 2006. С. 230-257.

\section{REFERENCES}

Vyhotskyi, 2003 - Vyhotskyi L. S. Psykholohyia razvytyia cheloveka. Moskva : «Smysl», «Eksmo», 2003. $1136 \mathrm{~s}$.

Dubovytskaia, 2005 - Dubovytskaia T. D. Metodyka dyahnostyky sytuatyvnoi samoaktualyzatsyy lychnosty: kontekstnyi podkhod. Psykholohycheskyi zhurnal. 2005. № 5. S. 70-78.

Koul, 1997 - Koul M. Kulturno-istorycheskaia psykholohyia: Nauka budushcheho / per. s anhl. Moskva : Kohyto-Tsentr, 1997. 432 s.

Mamardashvyly, 1992 - Mamardashvyly M. K. Kak ya ponymaiu fylosofyiu. Moskva : Kultura, 1992. $365 \mathrm{~s}$.

Radchuk, 2015 - Radchuk H. K. Psykholoho-pedahohichni zasady vprovadzhennia osvitnoho dialohu u navchalnyi protses vykladachamy VNZ. Problemy humanitarnykh nauk: Zbirnyk naukovykh prats Drohobytskoho derzhavnoho pedahohichnoho universytetu imeni Ivana Franka. Seriia «Psykholohiia». Drohobych : Vydavnychyi viddil DDPU imeni Ivana Franka, 2015. Vypusk trydtsiat piatyi. S. 85-101.

Starovoitenko, 2006 - Starovoitenko O. B. Problema subiekta v kulturnii psykholohii osobystosti. Liudyna. Subiekt. Vchynok: Filosofsko-psykholohichni studii / za zah. red. V. O. Tatenka. Kyiv: Lybid, 2006. S. 230-257.

\section{Ольга Склянська,} заступник директора КСЗНРЗ «Дніпропетровський обласний методичний ресурсний иентр» ДОР; аспірант відділу інклюзивного навчання Інституту спеціальної педагогіки і психологіі імені Миколи Ярмаченка НАПН Украӥни.
Olha Sklianska, Deputy Director in PSSERI «Dnipropetrovsk Regional Methodical Resource Center» DRC; postgraduate in Department of Inclusive Education of Mykola Yarmachenko Institute of Special Pedagogy and Psychology of NAES of Ukraine.

E-mail: olga.sklianska@gmail.com

ORCID: 0000-0003-3159-8765

\section{ПСИХОЛОГО-ПЕДАГОГІЧНИЙ СУПРОВІД ДИТИНИ РАННЬОГО ВІКУ 3 ОСОБЛИВИМИ ПОТРЕБАМИ В УМОВАХ ІНКЛЮЗИВНО- РЕСУРСНОГО ЦЕНТРУ}

\footnotetext{
Розглянуто моделі психолого-педагогічної допомоги дітям раннього віку та раннього втручання. Здійснено порівняння основних принципів та характеристик програм ранньої психолого-педагогічної допомоги та раннього втручання. Визначено провідні аспекти психологопедагогічної допомоги дітям раннього віку з позицій біопсихосоиіальної моделі інвалідності.
} 